\title{
Strategy under Uncertainty: Empirical Evidence from Swedish Companies Operating in Russia
}

\author{
Olga Golubeva ${ }^{1}$ \\ ${ }^{1}$ Department of Business Studies, School of Social Sciences, Södertörn University, Sweden \\ Correspondence: Olga Golubeva, Department of Business Studies, School of Social Sciences, Södertörn \\ University, SE-14189 Huddinge, Sweden. Tel: 46-8-608-5170. E-mail: olga.golubeva@sh.se
}

Received: February 23, 2016

Accepted: March 7, 2016

Online Published: April 18, 2016

doi:10.5539/ijbm.v11n5p44

URL: http://dx.doi.org/10.5539/ijbm.v11n5p44

\begin{abstract}
The objective of this paper is to describe and explain company strategies under uncertainty. The study attempts to examine closer interaction between research on strategic management and internationalization theory. Recent escalation of conflict between Russia and the EU/USA in combination with economic recession increased the level of uncertainty. The article explores how this deterioration is reflected in a strategy of Swedish companies operating in Russia. This study builds on the empirical data from a survey conducted in 2015 among 73 Swedish firms. The findings of the study contribute to knowledge regarding diversity in commitments shown by different companies at one particular point of time under the same circumstances. The study reveals a domination of expansion strategy chosen by Swedish firms during the current escalation of uncertainty in Russia. A growing strategy under uncertainty has seldom been reported and analyzed by scholars. The study demonstrated that uncertainty is not only a threat to companies operating on the market, but can lead to expanding strategies attempting to exploit the opportunities that uncertainty might offer. Appraising the risk concept, the study provides implications for companies' managers on the importance of a commitment decision to face the deterioration caused by the uncertainty. Empirical data from this study also suggest that uncertainty is handled by companies better than one might expect. The article questions whether companies and managers are really risk-averse in their behaviour.
\end{abstract}

Keywords: company strategy, uncertainty, Uppsala internationalization process model, rational and adaptive strategies, survey method, foreign (Swedish) investors, Russia

\section{Research Problem and Purpose}

In the present environment firms are increasingly exposed to the disturbances of a global marketplace and an escalation of uncertainty. A recognised expert in strategic management, Michael Porter, emphasized the importance of uncertainty for company strategy, suggesting that a firm might have to re-assess substantially its strategy if there are major changes in the level of uncertainty (Porter, 2006). There have been several attempts to link company strategy and uncertainty (Wiltbank et al., 2006; Kaplan, 2008). Complexities of the phenomena and data limitations, however, have impeded such development and discussion is far from being concluded (Toner et al., 2015).

Internationalization of companies, including expansion into emerging economies, is another distinguished feature of the modern economy. Compared to developed countries, markets in emerging countries are often exposed to a higher level of uncertainty. Only a few scholars, however, have included a risk dimension in their analyses of internationalization process. (Figueira de Lemos et al., 2011; Bengtson et al., 2013; Figueira-de-Lemos \& Hadjikhani, 2014).

Despite the fact that uncertainty and turbulence provide an increasingly common framework for the elaboration of international company strategy, the field of strategic management and research on internationalization of companies have tended to develop relatively separately. Any particular impact of the escalation of uncertainty on foreign companies' strategies also remains unclear.

The objective of this paper is to describe and explain foreign companies' strategies under the influence of uncertainty. The study attempts to examine closer interaction between research on strategic management and internationalization theory. The article's ambition is to search for a dynamic relationship between companies' 
strategies and uncertainty and explore why these strategies have been chosen by firms.

All companies operate nowadays under conditions of environmental uncertainty and high turbulence but the degrees of disturbance differ. Emergent post-socialist markets of Central and Eastern Europe (CEE), often labeled as transition economies, represent a pattern of uncertain and turbulent environment. It is pointed out by several researchers that transition economies are characterized by a higher degree of uncertainty, turbulence and ambiguity. (See Golubeva, 2001; Vasyechko, 2012; O’Donnell \& Schmitter, 2013).

The success of transition is often related to the progress of market reforms that decrease uncertainty and reduce turbulence. Courtney et al. (2000) stated, for example, that foreign companies considering investments in Russia in 1992 faced a true ambiguity with an unpredictable range of future outcomes for different scenarios. Since that time, greater political and regulatory stability have lowered the uncertainty level for strategic decisions of foreign companies entering the Russian market. Russia has been demonstrating successful reduction of the uncertainty level for over fifteen years.

There are several reasons, however, to believe that both economic and political uncertainties have recently escalated. Firstly, for the first time in a decade, the credit ratings agency Standard \& Poor's downgraded Russia's sovereign debt from an investment grade BBB- to a junk grade BB+, reflecting weakened prospects of economic growth. (Note 1). Secondly, relationships between Russia and the EU/USA have recently deteriorated. Introduction of sanctions against Russia by the EU and the USA, and counter-sanctions by the Russian government, have created challenges that were not on the agenda only a couple of years ago. Business Monitor International (BMI) views the current escalation of conflict between Russia and the West as being based on a long-term geopolitical competition and therefore likely to prevail for the next few years. (Note 2).

Several scholars have pointed out that joining the EU - or even the prospect of joining the EU - by transition economy countries promotes foreign investors (a halo effect). It has also been suggested that a multinational enterprise (MNE) may perceive a decrease of uncertainty if a transition country in which that MNE carries out foreign operations, integrates into the European Union market. (See Globerman et al., 2004). One might expect, therefore, that an escalation of conflict between Russia and the EU/USA in combination with economic recession will be reflected in a strategy of foreign companies operating in Russia.

This paper also aims to present and analyze the recent empirical survey data on the subject. While the entry strategies of MNEs into emerging markets and transition economies have been investigated by several scholars (Hultén, 2009; Arslan \& Larimo, 2011), the possible impact of an increased uncertainty on companies which are already established on the market is still an under-researched phenomena. The present study is limited to an analysis of strategies chosen by Swedish companies currently operating in Russia.

\section{Method}

The study uses the empirical data from the "Business Climate Survey 2015" (BCS) that was conducted by Business Sweden (Note 3) during March-April 2015. The survey presents the reaction of Swedish companies operating in Russia to the recent escalation of turbulence and uncertainty in the market. About 168 firms, approximately half of the Swedish companies operating in Russia, were asked to provide answers on 27 closed questions. Additionally, several questions allowed respondents to write comments and recommendations. The names of the companies and managers that participated in BCS are confidential.

The questions range from general information about the company to forward-looking strategy in Russia. 73 companies, or almost $43 \%$ of Swedish firms that had been randomly chosen to participate in the survey, provided answers. The actual respondents were experienced top executives, mainly Swedish nationals.

Many scholars in international management apply a longitudinal case study methodology, which allows them to follow the changing strategy of MNEs during a certain period of time (Johansson \& Johanson, 2006; Bengtson et al., 2013; Figueira-de-Lemos \& Hadjikhani, 2014). In contrast, this study uses empirical data received through a survey investigation. Such an approach excludes the possibility of following the changing pattern of company strategies over the long term. On the other hand, a survey method does allow the mapping of different strategies undertaken by numerous MNEs during a certain period of time, and searching for better understanding of why these strategies have been chosen by those companies. Analysis of different strategies chosen by MNEs at a particular point in time can eventually provide grounds for a more holistic view of the decision-making under conditions of increased uncertainty.

The remainder of the paper is structured as follows: first, we review the theoretical concepts relevant to the purpose of the study. Secondly, we present the empirical data and provide the analysis. We also compare findings of the study with other research. The last part concludes and suggests forward looking topics for future analysis. 


\section{Theoretical Framework}

\subsection{Strategy under Uncertainty}

Strategic management theory introduced numerous approaches to a company's strategy. (Note 4) Peng et al. (2008) applied an institution-based view to analyze international business strategy in emerging economies. Meyer et al. (2009) suggested integrating the institution-based view of strategy with resource-based considerations. Demirbag et al. (2007) combined institutional theory with transaction cost economics to analyse MNEs strategies in the emerging markets. Several scholars argued that different theoretical perspectives should be used to get useful insights into enterprise strategies in emerging economies.

For firms operating in the uncertain environment researchers often suggest two main directions: the classical planning approach and the adaptive learning approach. The classical planning school, the oldest one in strategic management, suggests that rational strategy can guide companies to better performance even in uncertain situations. Although predictions are too inaccurate to be useful under uncertainty, the systematic nature of rational planning is a valuable tool for a company strategy's development (Goyal et al., 2007; Jaeger et al., 2013). On the other hand, several scholars have suggested that changes in the turbulent and uncertain environment are bottom-up driven, emergent, and incremental, rather than formulated and implemented as assumed in the older classical strategic frameworks. The basic strategic principles of the emergent approach are incrementalism, experimentation and adaptation to the rapidly changing environment (Mason, 2007). Based upon the advice of these two schools, a company's strategy under uncertainty should either try harder to predict better (rational strategies), or move faster to adapt better (adaptive or emergent strategies) (Wiltbank et al., 2006).

Company strategy which is subject to uncertainty also involves a trade-off between acting early or waiting until the uncertainty is resolved. There are many arguments for managers operating under uncertainty to retain the status quo in the commitment (Pureza \& Laporte, 2008) and pursue a 'wait and see' strategy (Lowell, 2002). Sull (2005) advises companies that have chosen such a strategy to be ready to act as soon as it becomes possible to estimate the risks and rewards of the different scenarios, so-called 'active waiting'. An increased level of uncertainty might lead companies to choose a de-commitment (reduction) strategy (Petersen et al., 2008). Reported cases of de-commitment (Bianchi \& Ostale, 2006; Freeman et al., 2006) explain the logic of strategy to decrease the foreign commitment due to the knowledge loss under unfavorable changes of the environment. Research specifically focusing on exit strategy is relatively rare, although there have been some valuable contributions. (For example, Bianchi \& Ostale, 2006; Decker \& Mellewigt, 2007; Havila \& Salmi, 2009). In this position, companies are unable to cope with increased uncertainty and completely leave the foreign market. There is very little research on companies that have chosen an expanding (or growing) strategy under uncertainty. Expanding strategy presumes additional commitment by a company to the foreign market despite the increased uncertainty. The empirical evidence is quite rare, as companies prefer to wait before making further commitments until the risk level has become more acceptable.

Based upon strategic management' theories and concepts, the paper will focus on: (1) whether rational or adaptive strategy has been applied by companies operating under uncertainty; (2) how the choice between 'wait and see', de-commitment, exit and expanding strategies has been made and why these strategies have been chosen.

\subsection{Internationalization Process and Uppsala Model}

The classical economic model assumes that MNEs systemically engage in a cost-benefit analysis of different internationalization strategies and select the optimal one. Besides, growth is a core perspective in generating an understanding of reasons for internationalization of firms (Dunning, 2004).

The behavioral approach to analyzing foreign investment decisions has been developed by economists from Uppsala University in Sweden. The incremental behavior is realized through the increase of commitment against the decrease of uncertainty induced by knowledge accumulation (Johanson \& Vahlne, 1977). Based on Scandinavian experience, the model explains an increasing commitment in foreign countries from export to joint venture representation, then to sales subsidiary, and, finally, to resource development of the subsidiary. Furthermore, the model explains entry into the new markets with successively greater 'psychic' distance. Companies' increased knowledge about these foreign markets changes the perception of uncertainty, and investments previously assessed as risky become acceptable. In subsequent study, Johanson and Vahlne (2009) revised the Uppsala internationalization process model to emphasize environmental dynamics and to include knowledge gained through relationships in networks.

It is conceptually assumed in the framework that radical events escalate the uncertainty, and, consequently, the 
risk level. According to Jones (2007), uncertainty can be formulated as an event that might occur and can be planned for, i.e. addressed, in a set of contingency plans. Compared to 'pure uncertainty', reflecting unpredictability of future, 'contingent uncertainty' may be reduced through learning processes. A symmetrical relationship between 'contingent uncertainty' and knowledge has been established by Forsgren (2002), suggesting that acquisition of a certain amount of knowledge will reduce the same amount of 'contingent uncertainty'. Johanson and Vahlne (2009) explain the incremental commitment process during favorable developments. The question of what happens when the situation suddenly deteriorates, and 'contingent uncertainty' increases, needs further analysis and empirical testing. There is some evidence that unstable (and uncertain) environments require a tenuous compromise between knowledge and commitment decisions (Johanson \& Johanson, 2006).

Since the introduction of Uppsala model there have been limited contributions to develop risk formula. Figueira de Lemos et al. (2011) redefined risk as a function of commitment and uncertainty, $R=f(C$; $U)$. Uppsala internationalization process model puts three interconnected variables - uncertainty (knowledge), commitment and risk - at the center of analysis. According to Uppsala model, the increase in risk is directly correlated with an increase in the commitment while uncertainty remains unchanged. Risk increase can also happen as a result of an uncertainty increase due to, for example, radical changes in the investment environment. Although no empirical evidence accompanied the report, scholars formulated several hypotheses of possible decisions for different levels of commitments and uncertainty. The argument rests on the fact that firms do not avoid risk (Autio, 2005) but manage risk by balancing the levels of commitment and knowledge.

Recent work of Figueira-de-Lemos and Hadjikhani (2014) contributed an understanding of the mechanism of commitment decisions within crisis environments. Scholars analyzed empirical data collected through interviews with nine Swedish MNEs involved in foreign operations in Iran during the period from 1960 to 1992. The longitudinal analysis shows that when environmental changes are perceived as detrimental, firms tend to decrease their tangible assets and commit in a more intangible way. The study presents internationalization as a process of involvement which sometimes flows within incremental commitment and at other times with de-commitments.

For our study, we apply a framework of the Uppsala internationalization process model enhanced by a risk formula (Figueira de Lemos et al., 2011) and the contribution by Figueira-de-Lemos and Hadjikhani (2014). Our ambition is far removed from further development of the model itself. In the study we applied the conceptual framework of Uppsala model to map the empirical data and research strategies being chosen by firms under escalated uncertainty.

\section{Empirical Data Presentation and Analysis}

\subsection{Descriptive Empirical Statistics}

73 companies answered the questionnaire. Swedish firms that participated in the survey are engaged in sales (47\%), service sector (29\%), trading $(9 \%)$ and production activities (15\%). Five percent of companies entered the Russian market during the 1980s, 35\% - during the 1990s, $41 \%$ - during the 2000 s, and $19 \%$ after 2010.

Approximately half of the companies have a global turnover exceeding 500 MEUR, 20\% have a global turnover between 50 and 500 MEUR, and 28\%, less than 50 MEUR. Sales in the Russian market are moderate with only four percent of these companies generating a turnover above 500 MEUR, 20\% between 50 and 500 MEUR, 21\% between 10 and 50 MEUR, and 53\% less than 10 MEUR.

The main customer groups of the Swedish firms in Russia are: private companies (B2B) which represent $76 \%$ of sales, private consumers (B2C) for $12 \%$ of revenues, and governmental organizations (B2G), also for $12 \%$. The majority of companies that participated in the survey $(60 \%)$ are limited liabilities companies, the rest being opened join-stock companies, closed joint-stock companies, branch and representative offices. Appendix "Descriptive statistics of companies that participated in the survey" summarizes information about firms.

The group of companies that participated in the survey is rather diverse. These companies represent almost $20 \%$ of Swedish companies established in Russia.

Managers admitted that the current situation in Russia is characterized by a high level of uncertainty and faces significant volatility.

Companies reflected the challenges of the business environment in Russia:

- $\quad 91 \%$ of companies noticed no improvements in conducting business in Russia during the past two years;

- $\quad 63 \%$ of firms were negatively affected by the political tensions of 2014 ; 
- $42 \%$ of companies have been directly affected by the sanctions, trade embargos and import substitutions of foreign goods by locally produced items;

- $\quad 46 \%$ of companies had a negative turnover growth in 2014.

On the other hand, the survey demonstrated several positive signs. Firstly, the Swedish brand continues to be strong in Russia. $84 \%$ of companies assess that Sweden has a positive or very positive image in the Russian society. Secondly, profitability of Russian operations remains satisfactory. In $2014,54 \%$ of firms had a turnover according to, or better than, had been budgeted. Thirdly, despite the increased uncertainty and turbulence, Swedish executives expressed intentions to grow in Russia. Fourthly, Swedish executives expect that a reduction in uncertainty and economic recovery will happen in the short-term.

The following figures illustrate the positive signs expressed by the managers:

- $\quad 40 \%$ of companies made investments in 2014 ;

- $\quad 37 \%$ of firms plan investments in 2015 ;

- $\quad 59 \%$ believe that the recovery will happen already in 2016-2017.

A tentative conclusion is that, although Swedish investors admit challenges in connection with escalated political and economic uncertainty in Russia, their view remains rather positive.

\subsection{Some Findings Regarding Emergence of Strategy}

Executives were asked diverse questions including turnover' forecasts, marketing plans, geographical expansion, pricing strategy, inflation prognoses, investment strategy, staff and salary policies, local production' trends etc. Executives were able to provide exact answers to diverse questions posed in the survey. The answer "do not know" was found only in 5 out of 27 questions, and the proportion of managers that were not able to provide a response for these five items never exceeded $10 \%$. These response rates are reasons to assume that managers have a clear view on business developments.

"It is important to have an informed agenda for Russia based on your individual situation," explained a manager.

There are strong indications that Swedish companies have carried out extensive work elaborating and evaluating different scenarios of developments in Russia both for short-term and long-term perspectives. Variables that have been included in the analysis are diverse and range from prognoses regarding currency fluctuations and inflation trends to pricing strategy and salary developments. The current strategy employed by companies seems to be normative and rational although flexibility is allowed according to different scenarios.

It is impossible to draw a conclusion about the effectiveness of these planning efforts due to the absence of long-term observations. The analysis, however, suggests that predictions are commonly used as a strategy formation tool even under escalated uncertainty. The business goals are clearly translated into action and implementation plans. Although information is incomplete, it is good enough to be incorporated into strategic management plans.

"The business climate in Russia is definitely not easy. It might get worse before it will get better, but even in the toughest times there is business to be made," commented an executive.

Experimentation and 'trial and error', on the other hand, also have a place on the executives' agenda. Although targets are clearly defined, there is room for flexibility of implementation. We observed that several companies' investment plans can be postponed or even cancelled under unfavourable circumstances. During 2015, about 12\% of firms have revised their investments plans due to the changing assumptions.

Courtney et al. (2000) argue that company analysis under uncertainty is highly qualitative although managers can gain a valuable strategic perspective. To the contrary, in our study we formed an impression that besides general perspectives, managers assess upcoming trends, evaluate major risks and elaborate alternative scenarios. Our findings are more in line with conclusions made by Baum and Wally (2003) who advocated scenario-based, but rational decision-making under uncertainty. Kennedy and Avila (2013) also suggest improving decision-making under extreme uncertainty through dynamic blending of quantitative modelling and scenario planning.

Rational or emergent strategy? Recent contributions in strategic management attempt to bridge the gap between the planning and learning schools. Based upon some empirical evidence, Grant (2003), for example, suggested that companies under increased uncertainty de-emphasize partially their planning approach in exchange for creating more adaptive solutions. A balance of rationality prediction and learning adaption is labeled as 'planned emergence'. The empirical data from our study provides some support for Grant's suggestion. 


\subsection{Empirical Data on Strategies Chosen by Swedish Companies}

Following the conceptual framework of Uppsala model, we assume that uncertainty escalated from initial (lower) level $\mathbf{U}_{\mathbf{0}}$ to higher level $\mathbf{U}_{\mathbf{1}}$ while the companies' commitment remains at the same level $\mathbf{C}_{\mathbf{0}}$. The risk level rises with an increased uncertainty accompanied by a comparable decrease of knowledge that might be insufficient due to the new environmental challenges.

After an increase in uncertainty, the risk level has shifted from $\mathbf{R}_{\mathbf{0}}$ to $\mathbf{R}_{\mathbf{1}}$, which encourages the companies to elaborate a new strategy that should allow them to achieve the initial tolerable level of risk. An increase (or reduction) of foreign commitment $\mathbf{C}$ arises as a possible strategy in order to balance the escalated uncertainty.

The empirical data on strategies chosen by Swedish companies under escalated uncertainty in Russia is depicted on Figure 1 "Strategy under Uncertainty - empirical data summary".

In our study, 12 companies had not yet been able to make a decision. On Figure 1, this point is shown by the grey circle. Sooner or later, companies have to evaluate the available options and choose a suitable strategy.

Two firms decided to decrease the commitment, which would allow these companies to adjust the risk to the tolerable level. On Figure 1, this strategy is shown by the brown arrow. De-commitment (reduction) strategy was explained by the necessity of adjusting to the increased uncertainty and turbulence currently being experienced by the Russian market. "Slim organization, reduce footprint, outsource and out-staff," suggested a manager.

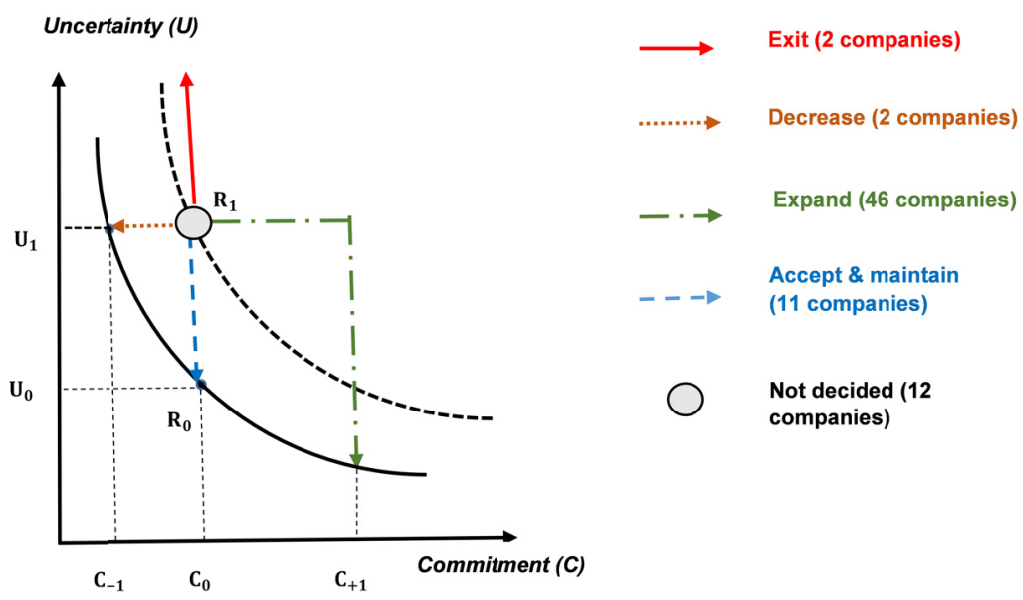

Figure 1. Strategy under uncertainty-empirical data summary

Two companies decided to leave Russia. On Figure 1 this strategy is shown by the red arrow. According to managers, an exit strategy is always an extreme outcome as it is expensive to re-establish. "Once you are gone, it is difficult to come back", acknowledged a manager. Despite the difficulties associated with re-establishment, their decision seems to be final as the uncertainty has exceeded the acceptable level. Unfortunately, no deeper explanation was given for the reasons that had pushed those companies out of the market. Scholars often point out that lack of a long-term strategy pushes MNEs towards exiting foreign markets.

Benito (2003), for example, argued that subsidiaries established as part of a global strategy are expected to be the least likely ones to be divested in the longer term. Bianchi and Ostale (2006) studied four multinational retailers in Chile and came to the conclusion that there was a lack of clear direction and targets for operating in the new market which led to the exit strategy. Epstein (2014) researched Western bank's strategy in CEE after the credit crunch in late 2008. According to the study, Western bank's strategy did not amount to 'cutting and running' when foreign bank investors in the region had long time horizons and high toleration for volatility.

In our study, complementary research with in-depth interviews is necessary to address the exit strategy. An acquired explanation about 'too high risks' perfectly suits the model, but does not provide insights into why some companies made a decision to exit while others planned to stay.

Eleven companies decided to continue operations 'as it is' without any changes in the commitment. Instead, these firms accepted the higher level of uncertainty and maintain the current position on the market. In Graphic 1, this strategy is shown by the blue arrow. Firms that pursued this strategy explained the choice by having the 
necessity "to survive the winter" and "be ready for improved situation". "Clients remember and cherish commitments," pointed out a manager.

Previous research suggests that under radical environmental changes 'wait and see' can be the most adequate approach (Pureza \& Laporte, 2008). According to Bengtson et al. (2013), even the proclamation that, unlike other competitors, Ericsson was not leaving Argentina during the crisis, lowered uncertainty. Our study also provides some support for an 'active waiting' strategy suggested by Sull (2005). Although firms have accepted uncertainty without additional commitments, they are prepared to act as soon as a clearer view on the development trends emerges.

Surprisingly, as many as 46 companies decided to pursue an expanding (or growing) strategy. On Figure 1, this strategy is shown by the green arrow. After an increase in commitment, the firms are expected to accumulate the amount of knowledge which is required to decrease the uncertainty until the risk returns back to its initial level. Companies that chose an expansion strategy argued that one should keep a long-term perspective in international business. It was also suggested that economic slowdown in Russia could be used to build a market share. Expansion can be achieved by utilizing cheaper resources alongside a lack of financing on the market and difficulties being experienced by the competitors.

"The Russian market is a long term game, the upside is there when the political situation improves," stated a manager.

Appraising the risk concept, the present study confirms the importance of a commitment decision to face the deterioration caused by the uncertainty. Furthermore, a strategy associated with an increased commitment was chosen by $63 \%$ of companies participating in the survey.

Some researchers pointed out that during uncertain periods, new possibilities might arise for those who stayed or entered the market (Kaplan, 2004; Epstein, 2014). On the other hand, McGrath and MacMillan (1995) suggested that uncertainty caused by the introduction of a new technology can be reduced by an investment in a company owning such know-how. However, the opposite applies in the case of 'external' uncertainty, when investments will not contribute to reduction of unpredictability. A 'wait and see' approach is, therefore, recommended by authors until critical uncertainties are resolved. This advice has not been supported by our empirical findings.

Empirical data, acquired through BCS, provided an opportunity to map strategies chosen by Swedish companies during the period of escalated uncertainty. Firms had revised the previously adapted strategy as a consequence of the increased uncertainty in order to adjust the risk back to the initial, tolerable level. Although an exit strategy had been chosen by only two companies, there is the important concern of why an exit became the best choice for these firms when others preferred to stay. Two companies decided to reduce the commitment and eleven firms accepted the higher level of uncertainty and continuing operations 'as it is'. These two strategies are very much in line with conclusions from numerous scholars. To retain a status quo without acting or slightly reducing the commitment seems to be a prudent approach under the increased uncertainty.

An 'expansion' strategy appeared to be a dominant choice in our study. To our knowledge, growing strategy under uncertainty has seldom been reported and analyzed by scholars. Based upon the empirical evidence, we suggest that the company's long-term objectives in the foreign market will impact the strategy choice under increased uncertainty. This topic, however, needs further investigation. What also tends to be lacking is the theoretical rationale for deciding which type of strategy (or mixture of types) should be adopted in particular investment environments. Other researchers are encouraged to follow up on these issues.

\section{Conclusions}

Traditional theory of investment decision-making commonly assumes that decisions are based on preferences and expectations about outcomes associated with different actions where the best possible alternative is chosen. Indeed, much of strategic management research is criticized as failing to take into account many factors, including uncertainty, which limit executives' abilities to develop strategy in a rational manner (Mansfield, 2013).

Our study suggests that companies continue to apply rationality and a deliberate planning approach during uncertainty and turbulent times. Strategy elaboration occurs when the major risks are identified, researched, quantified and integrated into the long-term objectives of a firm. Strategy is also flexible enough to adapt to the external challenges even if the aspiration to deliver favorable returns for shareholders remains constant. Forward-looking challenges include, in our view, further development of strategic risk management tools that can enable business rationality and profit maximization to co-exist with experimentation and bargaining. 
Foreign company strategy under uncertainty requires decisions that routinely involve risk and commitment. In the study we applied the conceptual framework of Uppsala internationalization process model to map and research strategies being chosen by firms under escalated uncertainty. Our ambition is far removed from further development of the model itself. We simply argue that valuable insights into decision-making under uncertainty can be achieved through application of the risk framework suggested by the model to research on companies' strategy.

The findings of our study contribute to knowledge regarding diversity in commitments shown by different companies at one particular point of time. The article suggests some explanations regarding the companies' motives for selecting one of the following strategies - exit, de-commitment, 'do nothing' and expansion. There is an obvious need to further extend our knowledge regarding diversity of commitment decisions chosen by different firms under the same pre-requisites.

Given that uncertainty may arise from a number of sources or may be characterized along a number of dimensions, it is necessary to develop further a concept of uncertainty and its impact on companies' strategies. In our study, we demonstrated that uncertainty is not only a threat to companies operating on the market, but can lead also to expanding strategies attempting to exploit the opportunities that uncertainty might offer. The latter endeavor will very quickly require much more formalized arguments than those used on the broad-brush level here.

It is reasonable to assume that acting early under uncertainty is riskier than waiting. The more risk-averse a firm is, the greater is the incentive for that firm to wait until uncertainty is resolved. Our findings, however, question whether companies and managers are really risk-averse in their behaviour. Empirical data from this study suggest that uncertainty is handled by companies better than one might expect. It is possible to assume that, as a result of international experience, today's MNE managers can exhibit greater variance in perceived uncertainty than did their earlier counterparts.

Since behavioral factors and bounded rationality were introduced into the research agenda, there has been an increasing trend towards acknowledging the role of individuals in foreign decision-making and related companies' strategies (Aharoni et al., 2011). Indeed, decision-making is based on several characteristics of the manager, including personal experience, knowledge, and tolerance for uncertainty and risk. It is possible that Swedish managers made strategic choices in Russia differently compared to executives from other countries operating in other markets. More studies examining managers' perceptions in different countries are required and future research would obviously benefit from cross- country comparisons of similarities and differences in the decision-making.

It is difficult to assess the potential for generalizing the particular findings of this study. What we hope for is that this research paper offers some new insights into internationalization phenomena and provides a constructive view of company strategies under uncertainty.

\section{Acknowledgments}

The author would like to thank Business Sweden, the Swedish Trade \& Invest Council, for providing the empirical data from its "Business Climate Survey 2015" for research purposes. The author is grateful for helpful comments from the anonymous referees. Comments from participants at the "GSOM Emerging Markets Conference: Business and Government Perspectives in St. Petersburg, Russia, 15-17 October 2015" are also acknowledged. The author is indebted to Dr. Alan Wood (UK) for proofreading assistance.

\section{References}

Aharoni, Y., Tihanyi, L., \& Connely, B. L. (2011). Managerial decision-making in international business: A forty-five-year retrospective. Journal of World Business, 46(2), 135-142. http://dx.doi:10.1016/j.jwb.2010.05.001

Arslan, A., \& Larimo, J. (2011). Greenfield investments or acquisitions: Impacts of institutional distance on establishment mode choice of multinational enterprises in emerging economies. Journal of Global Marketing, 24(4), 345-356. http://dx.doi:10.1080/08911762.2011.602323

Autio, E. (2005). Creative tension: The significance of Ben Oviatt's and Patricia McDougall's article 'Toward a theory of international new ventures'. Journal of International Business Studies, 36(1), 9-19. http://dx.doi:10.1057/palgrave.jibs. 8400117

Baum, J. R., \& Wally, S. (2003). Strategic decision speed and firm performance. Strategic Management Journal, 24(11), 1107-1129. http://dx.doi.org/10.1002/smj.343 
Bengtson, A., Ljung, A., \& Hadjikhani, A. (2013). Managing stability and crises in business relationships. The case of Ericsson in an emerging market. European Business Review, 25(6), 518-535. http://dx.doi.org/10.1108/EBR-01-2013-0007

Benito, G. R. G. (2003). Divestment seen through the lens of international business strategy. Paper presented at the International Conference on Divestment: Corporate Strategies, The Regions and Policy Responses, September 22-23, Lisbon. Retrieved from http://www.ceg.ul.pt/divest/Conf/benito_paper.pdf

Bianchi, C., \& Ostale, E. (2006). Lessons learned from unsuccessful internationalization attempts: Examples of multinational retailers in Chile. Journal of Business Research, 59(1), 140-147. http://dx.doi.org/10.1016/j.jbusres.2005.01.002

Courtney, H. G., Kirkland, J., \& Viguerie, S. P. (2000). Strategy under uncertainty. McKinsey Quarterly, June, 67-79. Retrieved

from

http://www.mckinsey.com/business-functions/strategy-and-corporate-finance/our-insights/strategy-under-un certainty

Decker, C., \& Mellewigt, T. (2007). Thirty years after Michael E. Porter: What do we know about business exit? Academy of Management Perspectives, 21(2), 41-55. http://dx.doi:10.5465/AMP.2007.25356511

Demirbag, M., Glaister, K. W., \& Tatoglu, E. (2007). Institutional and transaction cost influences on MNEs' ownership strategies of their affiliates: Evidence from an emerging market. Journal of World Business, 42(4), 418-434. http://dx.doi.org/10.1016/j.jwb.2007.06.004

Dubois, A., \& Gadde, L. E. (2002). Systematic combining: An abductive approach to case research. Journal of Business Research, 55(7), 553-560. http://dx.doi.org/10.1016/S0148-2963(00)00195-8

Dunning, J. H. (2004). An evolving paradigm of the economic determinants of international business activity. In J. Cheng, \& M. Hitt (Eds.), Advances in international management: Managing multinationals in a knowledge economy: Economics, culture, and human resources (Vol. 15, pp. 3-27). Oxford: Elsevier.

Epstein, R. A. (2014). When do foreign banks 'cut and run'? Evidence from west European bailouts and east European markets. Review of International Political Economy, 21(4), 847-877. http://dx.doi.org/10.1080/09692290.2013.824913

Figueira de Lemos, F., Johanson, J., \& Vahlne, J. E. (2011). Risk management in the internationalization process of the firm: A note on the Uppsala Model. Journal of World Business, 46(2), 143-153. http://dx.doi.org/10.1016/j.jwb.2010.05.008

Figueira-de-Lemos, F., \& Hadjikhani, A. (2014). Internationalization processes in stable and unstable market conditions: Towards a model of commitment decisions in dynamic environments. Journal of World Business, 49(3), 332-349. http://dx.doi.org/10.1016/j.jwb.2013.07.003

Forsgren, M. (2002). The concept of learning in the Uppsala internationalization process model: A critical review. International Business Review, 11(3), 257-277. http://dx.doi.org/10.1016/S0969-5931(01)00060-9

Freeman, S. M., Edwards, R., \& Schroder, B. (2006). How smaller born-global firms use network and alliances to overcome constraints to rapid internationalization. Journal of International Marketing, 14(3), 33-63. http://dx.doi.org/10.1509/jimk.14.3.33

Globerman, S., Shapiro, D., \& Tang, Y. (2004). Foreign direct investment in emerging and transition European countries. Working paper, Center for International Business, Western Washington University.

Golubeva, O. (2001). Foreign investment decision-making in transition economies. Doctoral dissertation, Stockholm: School of Business, Stockholm University.

Goyal, M., Smith, R. H., \& Netessine, S. (2007). Strategic Technology Choice and Capacity Investment Under Demand Uncertainty. Management Science, 53(2), 192-207. http://dx.doi.org/10.1287/mnsc.1060.0611

Grant, R. M. (2003). Strategic planning in a turbulent environment: Evidence from the oil majors. Strategic Management Journal, 24(6), 491-517. http://dx.doi.org/10.1002/smj.314

Havila, V., \& Salmi, A. (2009). Managing Project Ending. London: Routledge.

Hultén, P. (2009). Swedish SMEs' establishment of business in Russia: A case study. Journal of East-West Business, 15(1), 5-24. http://dx.doi.org/10.1080/10669860902900206

Jaeger, C. C., Renn, O., Rosa, E. A., \& Webler, T. (2013). Risk, Uncertainty, and Rational Action. Risk, Society, and Policy series. Routledge. 
Johanson, J., \& Vahlne, J. E. (1977). The internationalization process of the firm-A model of knowledge development and increasing foreign market commitments. Journal of International Business Studies, 8(1), 23-32. http://dx.doi.org/10.1057/palgrave.jibs. 8490676

Johanson, J., \& Vahlne, J. E. (2009). The Uppsala internationalization process model revisited-From liability of foreignness to liability of outsidership. Journal of International Business Studies, 40(9), 1411-1431. http://dx.doi.org/10.1057/jibs.2009.24

Johanson, M., \& Johanson, J. (2006). Turbulence, discovery and foreign market entry: A longitudinal study of an entry into the Russian market. Management International Review, 46(2), 179-205. Retrieved from http://www.jstor.org/stable/40836081

Jones, G. (2007). Organizational theory, design and change (5th ed.). Upper Saddle River, NJ: Pearson Prentice Hall.

Kaplan, S. (2008). Framing contests: strategy making under uncertainty. Organization Science, 19(5), 729-752. http://dx.doi.org/10.1287/orsc. 1070.0340

Kennedy, P. J., \& Avila, R. J. (2013). Decision making under extreme uncertainty: Blending quantitative modelling and scenario planning. Strategy \& Leadership, 41(4), 30-36. http://dx.doi.org/10.1108/SL-04-2013-0025

Lowell, L. B. (2002). Just-in-time strategy for a turbulent world. McKinsey Quarterly. Retrieved from http://www.mckinsey.com/insights/strategy/just-in-time_strategy_for_a_turbulent_world

Mansfield, R. (2013). Company Strategy and Organizational Design. Routledge Library editions: Organizations: theory \& behavior. London \& Sydney: Routledge.

Mason, R. B. (2007). Management Decision, 45(1), 10-28. http://dx.doi.org/10.1108/00251740710718935

McGrath, R. G., \& MacMillan, I. C. (1995). Discovery-Driven Planning. Harvard Business Review, July-August. Retrieved from https://hbr.org/1995/07/discovery-driven-planning

Meyer, K. E., Estrin, S., Bhaumik, S. K., \& Peng, M. W. (2009). Institutions, resources, and entry strategies in emerging economies. Strategic Management Journal, 30(1), 61-80. http://dx.doi.org/10.1002/smj.720

Morais, R. (2010). Scientific method. In A. Mills, G. Durepos \& E. Wiebe (Eds.), Encyclopedia of case study research (pp. 840-842). Thousand Oaks, CA: Sage.

O’Donnell, G., \& Schmitter, P.C. (2013). Transition from Authoritation Rule. Tentative Conclusions about Uncertain Democracies. The John Hopkins University Press: Baltimore.

Peng, M. W., Wang, D. Y. L., \& Jiang, Y. (2008). An institution-based view of international business strategy: A focus on emerging economies. Journal of International Business Studies, 39, 920-936. http://dx.doi.org/10.1057/palgrave.jibs. 8400377

Petersen, B, Pedersen, T., \& Lyles, M. (2008). Closing knowledge gaps in foreign markets. Journal of International Business Studies, 39(7), 1097-1113. http://dx.doi.org/10.1057/palgrave.jibs.8400409

Porter, M. (2006). What is strategy. In M. Mazzucato (Ed.), Strategy for business: A reader (pp. 10-31). SAGE Publications Limited.

Pureza, V., \& Laporte, G. (2008). Waiting and buffering strategies for the dynamic pickup and delivery problem with time windows. INFOR, Information Systems and Operational Research, 46(3), 165-175. http://dx.doi.org/10.3138/infor.46.3.165

Sull, D. N. (2005). Strategy as active waiting. Harvard Business Review, 121-129.

Toner, M., Ojha, N., De Paepe, P., \& De Melo, M. S. (2015). A Strategy for Thriving in Uncertainty. Bain Brief, August, $12 . \quad$ Retrieved from http://www.bain.com/publications/articles/a-strategy-for-thriving-in-uncertainty.aspx

Vasyechko, O. A. (2012). Review of FDI theories: An application for transition economies. International Research Journal of Finance \& Economics, 89, 118-137.

Whittington, R. (2006). Theories of Strategy. In M. Mazzucato (Ed.), Strategy for business: A reader (pp. 32-58). SAGE Publications Limited.

Wiltbank, R., Dew, N., Read, S., \& Sarasvathy, S. D. (2006). What to do next? The case for non-predictive strategy. Strategic Management Journal, 27(10), 981-998. http://dx.doi.org/10.1002/smj.555 


\section{Notes}

Note 1. Andrianova, A., \& Galouchko, K. (2015, January, 26). Russia credit rating is cut to junk by S\&P for the first time in a decade. Bloomberg. Retrieved from http://www.bloomberg.com/news/articles/2015-01-26/russia-credit-rating-cut-to-junk-by-s-p-for-first-time-in-de cade

Note 2. Russia and the West: Not a new cold war, but a cooler period (2014, November 11), Business Monitor International (BMI), A Fitch Group Company. Retrieved from http://www.businessmonitor.com/news-and-views/russia-and-the-west-not-a-new-cold-war-but-a-cooler-period\#s thash.V7JM1eVj.dpuf

Note 3. Business Sweden, the Swedish Trade \& Invest Council, was founded on January 1, 2013, to facilitate the growth of Swedish companies abroad and investment opportunities in Sweden. Business Sweden is owned by the Swedish government and has representation in 50 countries.

Note 4. We refer to a comprehensive work by Richard Whittington (2006) for review of the main approaches to strategy, namely the classical school, the evolutionary and processual perspectives, and the systemic approach.

\section{Appendix "Descriptive statistics of companies that participated in the survey"}
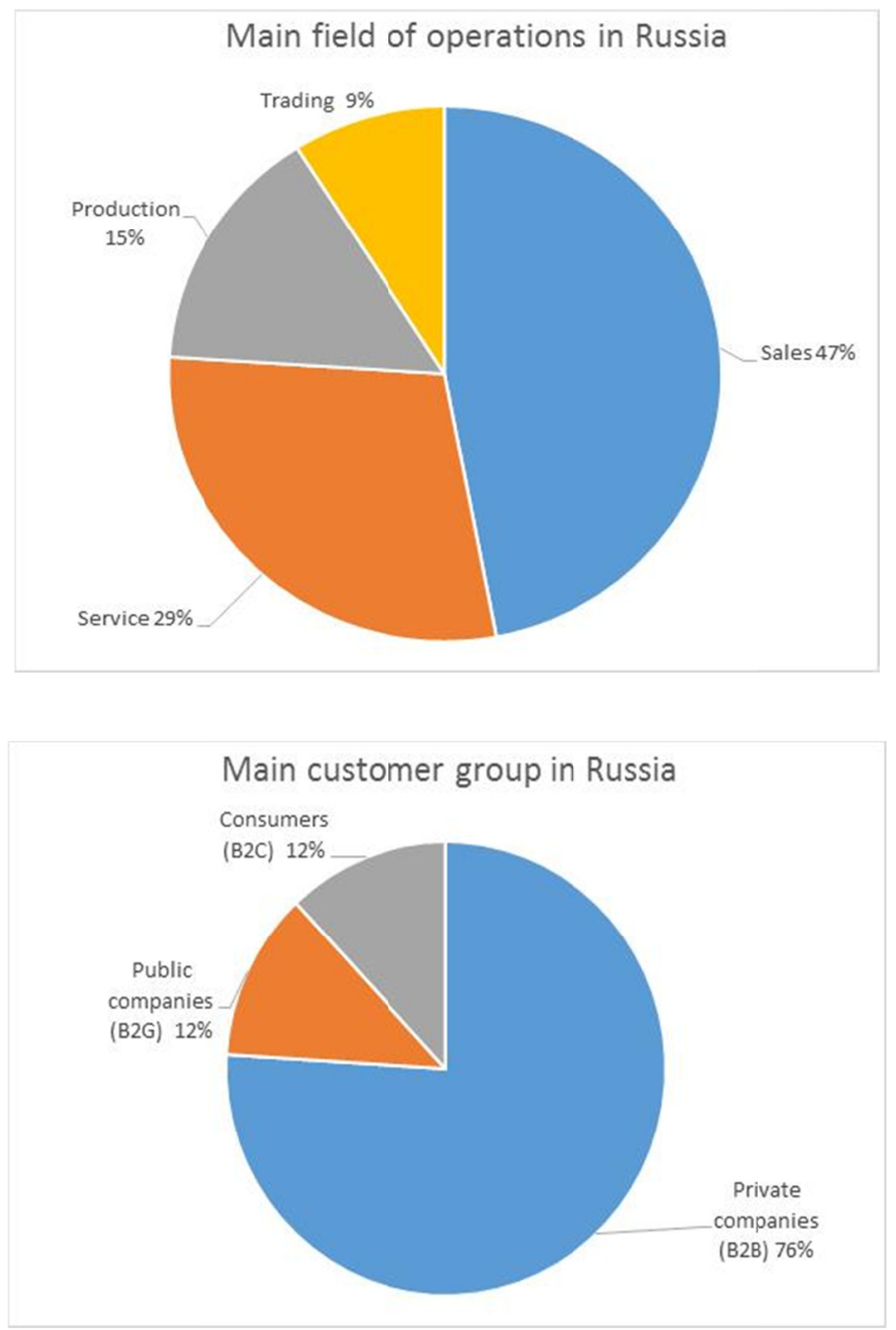

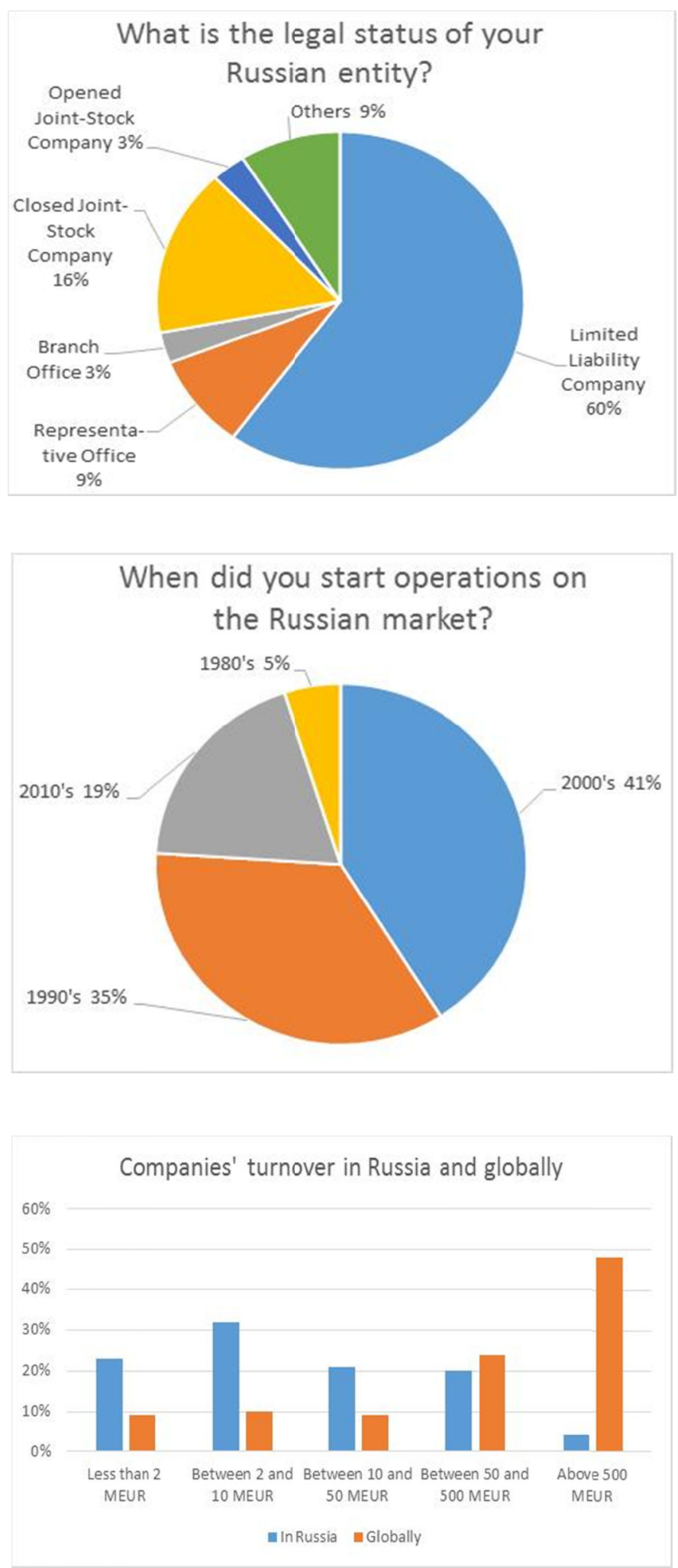


\section{Copyrights}

Copyright for this article is retained by the author(s), with first publication rights granted to the journal.

This is an open-access article distributed under the terms and conditions of the Creative Commons Attribution license (http://creativecommons.org/licenses/by/3.0/). 